US Army Corps

of Engineers ${ }_{\circledast}$

Engineer Research and

Development Center

Mercury Isotopes Reveal Atmospheric Gaseous Mercury Deposition Directly to the Arctic Coastal Snowpack

Thomas A. Douglas and Joel D. Blum

June 2021 
The U.S. Army Engineer Research and Development Center (ERDC) solves the nation's toughest engineering and environmental challenges. ERDC develops innovative solutions in civil and military engineering, geospatial sciences, water resources, and environmental sciences for the Army, the Department of Defense, civilian agencies, and our nation's public good. Find out more at www.erdc.usace.army.mil.

To search for other technical reports published by ERDC, visit the ERDC online library at https://erdclibrary.on.worldcat.org/discovery. 


\section{Mercury Isotopes Reveal Atmospheric Gaseous Mercury Deposition Directly to the Arctic Coastal Snowpack}

Thomas A. Douglas

Cold Regions Research Laboratory

U.S. Army Engineer Research and Development Center

PO Box 35170

Fort Wainwright, Alaska 99703

Joel D. Blum

Department of Earth and Environmental Sciences

University of Michigan

1100 N University Avenue

Ann Arbor, MI 48109

Final report

Approved for public release; distribution is unlimited.

Prepared for National Science Foundation, Office of Polar Programs

Alexandria, Virginia 22314

Under Grant Numbers ARC-0435989 and ARC-0435893 


\section{Preface}

This study was conducted for the U.S. National Science Foundation, Office of Polar Programs, under Grant Number ARC-0435989 and University of Michigan, Grant Number ARC-0435893.

The work was performed by the Biogeochemical Sciences Branch of the Research and Engineering Division, U.S. Army Engineer Research and Development Center, Cold Regions Research and Engineering Laboratory (ERDC-CRREL). At the time of publication, Dr. Justin B. Berman was Branch Chief, and Dr. George Calfas was Division Chief. The Deputy Director of ERDC-CRREL was Mr. David B. Ringelberg, and the Director was Dr. Joseph L. Corriveau.

Extensive logistical support was provided by the Barrow Arctic Science Consortium, and their assistance is greatly appreciated. Numerous colleagues assisted with sample collection and hearty discussions of the Arctic mercury cycle, particularly M. Sturm, C. Polashenski, A. Steffen, and L. Sherman. We thank anonymous reviewers for their comments on earlier versions of the manuscript.

This paper was originally published by the American Chemical Society in the Environmental Science and Technology Letters on 7 March 2019.

The Commander of ERDC was COL Teresa A. Schlosser and the Director was Dr. David W. Pittman.

DISCLAIMER: The contents of this report are not to be used for advertising, publication, or promotional purposes. Citation of trade names does not constitute an official endorsement or approval of the use of such commercial products. All product names and trademarks cited are the property of their respective owners. The findings of this report are not to be construed as an official Department of the Army position unless so designated by other authorized documents. 


\title{
Mercury Isotopes Reveal Atmospheric Gaseous Mercury Deposition Directly to the Arctic Coastal Snowpack
}

\begin{abstract}
Springtime atmospheric mercury depletion events (AMDEs) lead to snow with elevated mercury concentrations (>200 ng Hg/L) in the Arctic and Antarctic. During AMDEs gaseous elemental mercury (GEM) is photochemically oxidized by halogens to reactive gaseous mercury which is deposited to the snowpack. This reactive mercury is either photochemically reduced back to GEM and re-emitted to the atmosphere or remains in the snowpack until spring snowmelt. GEM is also deposited to the snowpack and tundra vegetation by reactive surface uptake (dry deposition) from the atmosphere. There is little consensus on the proportion of AMDE-sourced $\mathrm{Hg}$ versus $\mathrm{Hg}$ from dry deposition that is released in spring runoff. We used mercury stable isotope measurements of GEM, snowfall, snowpack, snowmelt, surface water, vegetation, and peat from a northern Alaska coastal watershed to quantify $\mathrm{Hg}$ sources. Although high $\mathrm{Hg}$ concentrations are deposited to the snowpack during AMDEs, we estimate that $\sim 76$ to $91 \%$ is released back to the atmosphere prior to snowmelt. Mercury deposited to the snowpack as GEM comprises the majority of snowmelt $\mathrm{Hg}$ and has a $\mathrm{Hg}$ stable isotope composition similar to $\mathrm{Hg}$ deposited by reactive surface uptake of GEM into the leaves of trees in temperate forests. This GEM-sourced $\mathrm{Hg}$ is the dominant $\mathrm{Hg}$ we measured in the spring snowpack and in tundra peat permafrost deposits.
\end{abstract}

\section{INTRODUCTION}

Elevated mercury $(\mathrm{Hg})$ concentrations have been reported in Arctic coastal snow and ice far from emission sources. ${ }^{1,2}$ This is of concern because $\mathrm{Hg}$ can be transformed into its more toxic form, methylmercury, in Arctic wetlands which can be readily biomagnified in aquatic and terrestrial food webs. ${ }^{3-5}$ Elevated $\mathrm{Hg}$ levels have been reported in fish and piscivorous mammals, both of which are major staples in Arctic subsistence diets. ${ }^{6}$ Since the Arctic is snow and ice covered for up to nine months a year, a majority of the surface water runoff occurs during spring melt. ${ }^{7}$ A major wintertime source of $\mathrm{Hg}$ deposition has been attributed to atmospheric mercury depletion events (AMDEs), which are driven by photochemical reactions mediated by reactive halogen compounds in snow and ice., ${ }^{8,9}$ During AMDEs, gaseous elemental $\mathrm{Hg}, \mathrm{Hg}(0)$, is oxidized to reactive gaseous mercury, $\mathrm{Hg}(\mathrm{II})$, which is readily deposited to snow and ice surfaces. ${ }^{10-12}$ In addition to the AMDE process, $\mathrm{Hg}$ is deposited to the Arctic by reactive deposition of $\mathrm{Hg}(0)$ directly from the atmosphere to the snowpack and tundra vegetation. ${ }^{13}$ This $\mathrm{Hg}(0)$ can be oxidized and retained in the snowpack, vegetation, and soils; however, the mechanism by which $\mathrm{Hg}(0)$ enters the snowpack and is oxidized is not wellknown. The snowpack halogen content in Arctic coastal regions is elevated, ${ }^{14}$ and this, along with the catalytic properties of snow and ice crystal surfaces, ${ }^{15}$ implicates halogens in the $\mathrm{Hg}$ oxidation process. ${ }^{16}$ Sea ice, particularly in refreezing open leads, is the dominant source of reactive halogens to the coastal environment. ${ }^{14,17-19}$

$\mathrm{Hg}$ (II) produced in the atmosphere from AMDEs and $\mathrm{Hg}$ (II) produced in the snowpack from reactive surface uptake of $\mathrm{Hg}(0)$ (hereafter referred to as "dry deposition") can be photochemically reduced to $\operatorname{Hg}(0)$ and emitted back to the atmosphere, or it can remain in the snowpack to become a component of spring melt runoff. ${ }^{20,21}$ Estimates of the percent of AMDE-sourced $\mathrm{Hg}$ remaining in the snowpack a week after active AMDE deposition range from 5 to $60 \%$ with higher retention reported predominantly from coastal locations. ${ }^{22,23}$ $\mathrm{Hg}$ (II) deposited during AMDEs is generally associated with snowfall and dry deposition of small ( $\mathrm{mm}$ in diameter) ice crystals (diamond dust ${ }^{2}$ ). However, $\mathrm{Hg}(0)$ can infiltrate into snowpack pore spaces and become oxidized to $\mathrm{Hg}$ (II) within the snowpack throughout the winter. Thus, exposure to sunlight, which is needed for photochemical reduction reactions, is expected to be greater for AMDE $\mathrm{Hg}(\mathrm{II})$, which is deposited at the snow surface compared to $\operatorname{Hg}(0)$, which is deposited within the snowpack by oxidation to $\mathrm{Hg}$ (II). It has also been postulated that $\mathrm{Hg}$ (II) in halogen-rich snow is less 
likely to undergo photoreduction than in halogen-poor snow. ${ }^{10,24}$ Because inland snowpacks have markedly lower halogen ion concentrations compared to coastal sites, ${ }^{25}$ we would expect a decrease in total $\mathrm{Hg}$ deposition and an increase in the percent loss of $\mathrm{Hg}$ from the snowpack through reemission with increasing distance inland. Coastal sites are also more likely than inland ones to have identifiable amounts of AMDE-deposited $\mathrm{Hg}$ and higher snowpack $\mathrm{Hg}$ concentrations.

The contribution of total yearly $\mathrm{Hg}$ deposition attributable to AMDEs in the Arctic versus deposition of $\mathrm{Hg}(0)$ from dry deposition has not been well-quantified. However, a recent long-term $\mathrm{Hg}$-deposition mass balance study that focused on $\mathrm{Hg}$ sources and sinks at an Arctic Alaskan tundra site $\sim 200 \mathrm{~km}$ inland from the coast (Toolik Lake) concluded that little $(\sim 5 \%)$ of the $\mathrm{Hg}$ in the tundra was attributable to $\mathrm{Hg}$ (II) from wet deposition including AMDEs, while the majority (7390\%) of the $\mathrm{Hg}$ present in the tundra was deposited from atmospheric $\operatorname{Hg}(0) .^{13}$

In another recent study at a coastal site near Utqiagvik Alaska (formerly known as Barrow) an ionic pulse of elevated major ions and $\mathrm{Hg}$ was identified in a small (2.5 ha) watershed during spring snowmelt runoff periods for two subsequent years. ${ }^{21}$ Total dissolved $\mathrm{Hg}$ meltwater runoff ranged between 8 and $14 \mathrm{ng} / \mathrm{ha}$ in the two years studied. This is up to 7 times greater than runoff reported from noncoastal Arctic locations ${ }^{26,27}$ and markedly greater than runoff from temperate watersheds. $^{28}$ It was calculated that $41 \%$ and $78 \%$ of the premelt snowpack total $\mathrm{Hg}$ exited the watershed in stream discharge during each of the two spring snowmelt periods, respectively. From these results and time-series measurements of $\mathrm{Hg}$ in the snowpack and in meltwater throughout the runoff period it was estimated that $\sim 25 \%$ of the $\mathrm{Hg}$ in spring melt runoff at the coastal study location was attributable to AMDE Hg. $^{21}$

Numerous studies have established the use of $\mathrm{Hg}$ stable isotopes to identify $\mathrm{Hg}$ sources and track both photochemical and dark reactions in the environment. ${ }^{29}$ It has been wellestablished that photochemical reactions impart large magnitude mass independent fractionation (MIF) and mass dependent fractionation (MDF), whereas non-photochemical reactions impart almost entirely MDF. ${ }^{29,30}$ Snow deposited during AMDEs has $\mathrm{Hg}$ isotope ratios with MDF similar to atmospheric GEM but with lower MIF than GEM, indicative of photochemical oxidation of atmospheric $\mathrm{Hg}(0)$ followed by deposition of $\mathrm{Hg}(\mathrm{II})$ with snowfall. ${ }^{12,31}$

A study of particular relevance to this study ${ }^{31}$ identified that photochemical reduction of $\mathrm{Hg}(\mathrm{II})$ to $\mathrm{Hg}(0)$ in the Arctic snowpack after deposition produced MIF with decreasing $\Delta^{199} \mathrm{Hg}$ and $\Delta^{201} \mathrm{Hg}$ in residual snowpack $\mathrm{Hg}(\mathrm{II})$. Another study of relevance to this work ${ }^{32}$ showed that the oxidation of atmospheric $\operatorname{Hg}(0)$ within the leaves of plants results in no MIF but imparts an MDF with a shift of ca. $-2.0 \%$ in $\delta^{202} \mathrm{Hg}$ between $\mathrm{Hg}(0)$ in the atmosphere and $\mathrm{Hg}(\mathrm{II})$ deposited in leaves. A study of boreal forest runoff identified foliar uptake by vegetation, not wet precipitation, as the dominant $\mathrm{Hg}$ source. ${ }^{33}$ The results of these and other studies were used to help interpret $\mathrm{Hg}$ isotope measurements in a previous study of atmosphere, rain, snow, and soils from Toolik Lake Alaska, $\sim 200 \mathrm{~km}$ inland from the Arctic Coast. ${ }^{13}$ From this it was concluded that the majority of the $\mathrm{Hg}$ flux to the inland tundra $(\sim 70 \%)$ was via $\mathrm{Hg}(0)$ deposition to vegetation and soil. This paper $^{13}$ further argued that neither rain nor AMDE snow contributed significantly to the air-surface $\mathrm{Hg}$ flux. This study was particularly important, because it was the first to conclusively demonstrate that elevated $\mathrm{Hg}$ levels in Arctic soils are driven by reactive surface uptake of $\mathrm{Hg}(0)$ rather than $\mathrm{Hg}(\mathrm{II})$ deposition.

The Toolik Lake study ${ }^{13}$ motivated us to synthesize $\mathrm{Hg}$ isotope measurements that we made on samples from Utqiagvik, Alaska, as a comparison location from the Arctic coast in contrast to the previous study ${ }^{13}$ performed $\sim 200 \mathrm{~km}$ inland. Our study design utilized sampling the outflow of a closed catchment and allowed us to quantify the mass balance of $\mathrm{Hg}$ released by melting of the snowpack. ${ }^{21}$ Numerous studies have shown higher $\mathrm{Hg}$ concentrations in coastal compared to inland snowpacks in the Arctic. ${ }^{10,26,27,34,35}$ This is also the case when comparing Toolik Lake snow (0.4-12.5 $\mathrm{ng} / \mathrm{L})^{13}$ to Utqiagivik snow $(4.1$ to $>1000 \mathrm{ng} / \mathrm{L}) .{ }^{11,36}$

\section{MATERIALS AND METHODS}

2.1. Study Site. To track the processes by which $\mathrm{Hg}$ is deposited from the atmosphere to the Arctic Coastal land surface we measured $\mathrm{Hg}$ stable isotopes from a variety of environmental compartments during a spring melt runoff mass balance study in 2008. ${ }^{21}$ Our sampling was focused at the snowNET site on the Arctic Coastal Plain of Alaska $6 \mathrm{~km}$ southeast of Utqiagvik $\left(71.285^{\circ} \mathrm{N}, 156.575^{\circ} \mathrm{W}\right.$; Figure 1$)$. The

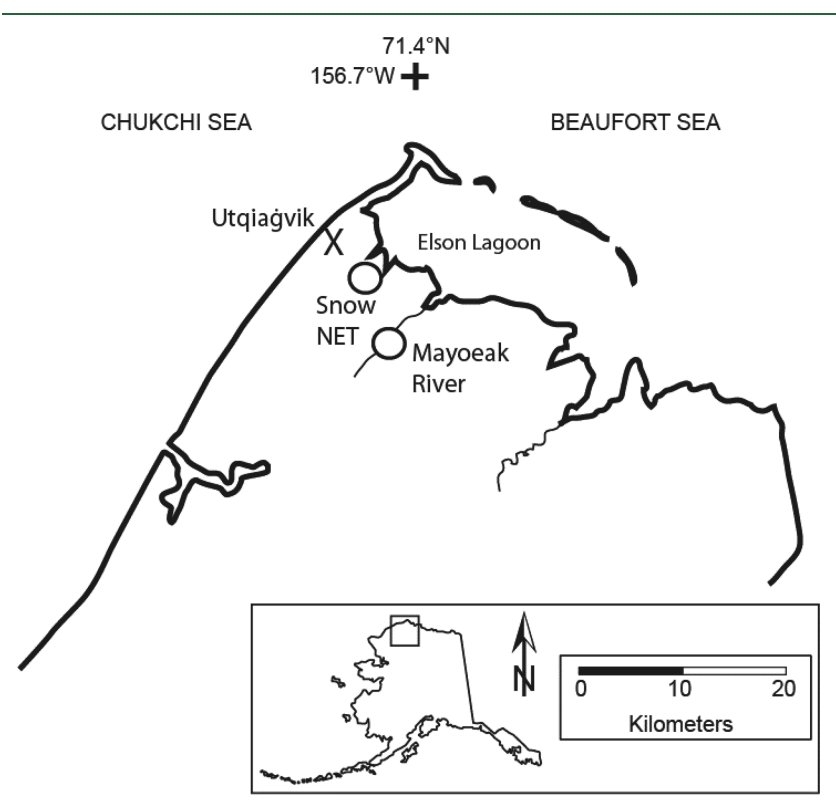

Figure 1. A map of the study site identifying the location of sample collections and the physiography of the area.

site, in the Barrow Environmental Observatory, is far from any major infrastructure, is underlain by continuous permafrost hundreds of meters thick, and has a low topographic relief with high and low centered ice wedge polygons. ${ }^{37}$ Soils are gelisols with a thin $(5 \mathrm{~cm})$ surface mat of sedges over a $2 \mathrm{~m}$ thick icerich organic peat layer above silty clays and silty loams. ${ }^{38}$ The small (2.5 ha) experimental catchment drains eastward into Elson Lagoon, which is connected to the Arctic Ocean.

At our study site near Utqiagvik we collected samples of the integrated snowpack, meltwater percolating downward through the snowpack, and surface runoff over frozen tundra. We previously published $\mathrm{Hg}$ concentrations and isotopic compositions of atmospheric $\operatorname{Hg}(0),{ }^{31}$ fresh snowfall, ${ }^{2,36}$ surface and 
ㄴํㅇ :

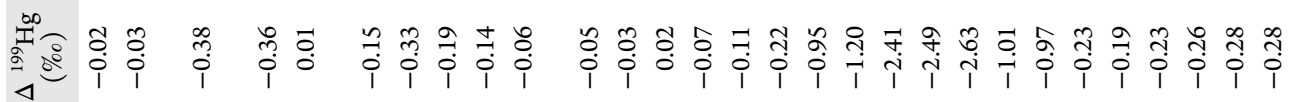

월 :

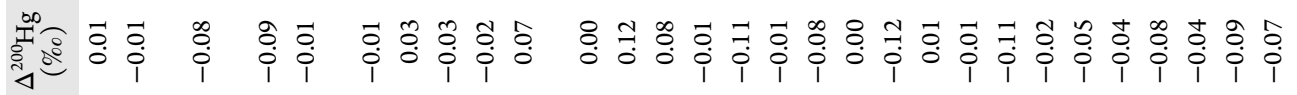

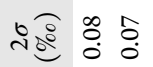

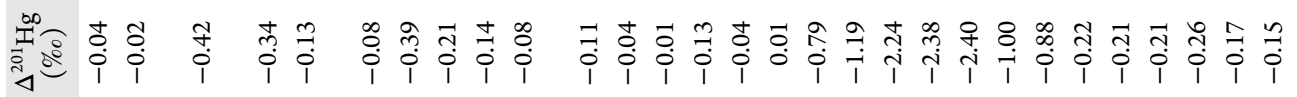

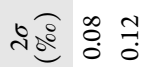

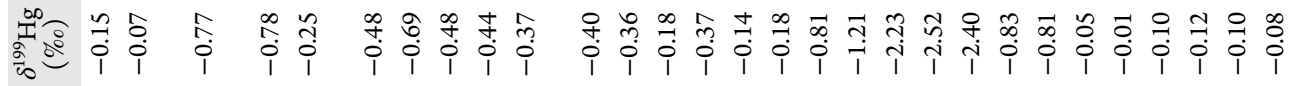

웡

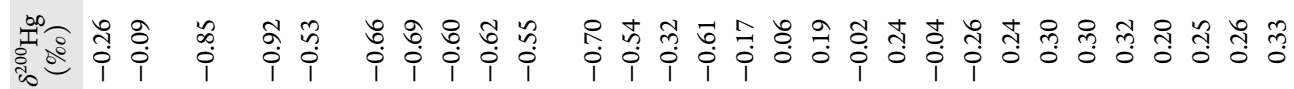

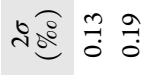

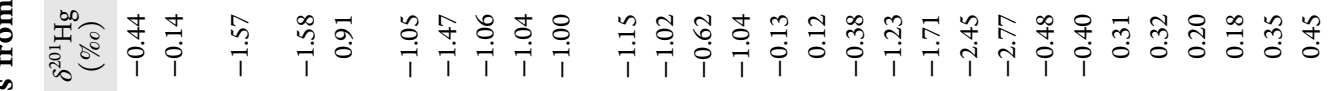

종ำ웡

范

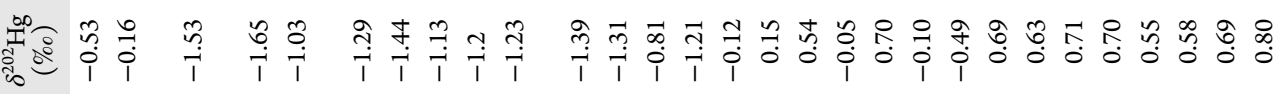

䆜

过

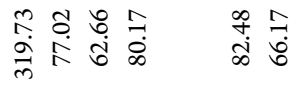

고

施

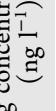

苟敬

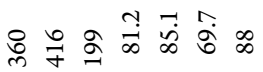

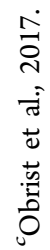

I 
aged snow, ${ }^{11}$ and peat cores ${ }^{39}$ from the same area. Detailed sampling information is provided in the Methods section.

2.2. Sample Collection. All snowpack and water sampling materials and Teflon bottles were cleaned in a metal-free clean laboratory using acetone, Citrinox soap, nitric acid, and $\mathrm{BrCl}$ followed by five deionized water rinses. Bottles were double sealed in cleaned acid-washed polypropylene bags. Water samples were drawn into cleaned high density polyethylene (HDPE) syringes and collected into poly(tetrafluoroethylene) (PTFE; Teflon) $250 \mathrm{~mL}$ bottles (total mercury) and $1 \mathrm{~L}$ jars (mercury stable isotopes); all water and snow samples were frozen immediately following collection.

On May 28, 2008, meltwater samples were collected at the base of a small $(2 \mathrm{~m} \times 1 \mathrm{~m})$ trench excavated through the 15 $\mathrm{cm}$ deep snowpack. Extensive care was taken to ensure the snowpack and snowmelt water samples did not include snow or meltwater that had been in contact with the underlying tundra vegetation. A thin, acid-cleaned $2 \mathrm{~m}^{2}$ Teflon sheet was slid gently horizontally between the vegetation surface and the base of the snowpack so we could collect only meltwater percolating through the snowpack prior to it interacting with vegetation or soils. Snowmelt water actively pooling onto the Teflon sheet was collected on May 28 and June 1. It took 20 min to fill a $1 \mathrm{~L}$ sample bottle.

To sample the integrated snowpack on June 9 we used a 10 $\mathrm{cm}$ diameter polyvinyl chloride tube with a serrated end that was rotated gently downward into the snowpack to a Teflon scoop inserted into the snowpack following previously described methods. ${ }^{27}$ The corer was inserted gently from the surface to the base of the snowpack ensuring no layers were preferentially collected or excluded. Snow around the corer was removed with an HDPE shovel and a clean HDPE scoop was slid under the base of the corer to ensure it did not come in contact with the underlying vegetation. The corer was then tipped upside down; 10 of these cores collected $1 \mathrm{~m}$ apart from one another to represent a $10 \mathrm{~m}^{2}$ area were combined into one cleaned $3 \mathrm{~L}$ Teflon sample bottle.

Surface runoff was collected from the Mayoeak River (19 $\mathrm{km}^{2}$ drainage basin) at a location $5 \mathrm{~km}$ southeast of the study watershed on June 10 into $250 \mathrm{~mL}$ (total $\mathrm{Hg}$ ) and $1 \mathrm{~L}(\mathrm{Hg}$ stable isotopes) cleaned Teflon bottles. The terrain, vegetation, and snowpack of the Mayoeak River watershed are similar to the smaller experimental watershed nearby. Our samples were analyzed for total $\mathrm{Hg}$ and mercury stable isotope ratios $\left(\delta^{202} \mathrm{Hg}, \Delta^{199} \mathrm{Hg}, \Delta^{200} \mathrm{Hg}, \Delta^{201} \mathrm{Hg}, \Delta^{202} \mathrm{Hg}\right.$, and $\Delta^{204} \mathrm{Hg}$; Table $1)$. Methods for sample container cleaning and sample collection for the analysis of $\mathrm{Hg}$ concentrations and isotopic compositions have been published previously. ${ }^{12,36,40}$

In July 2008 we collected a shallow $(30 \mathrm{~cm})$ sample of the vegetation mat and upper soil from the center of a high centered ice wedge polygon using a clean serrated ceramic knife. This represents the "active layer" above the permafrost that thaws in the summer. In addition, we used a CRREL/ Snow, Ice, and Permafrost Research Establishment (SIPRE) 8 $\mathrm{cm}$ diameter corer to collect a full $1.5 \mathrm{~m}$ core from the SnowNET site in late Oct 2008. Both cores were divided into 10 to $20 \mathrm{~cm}$ long sections, placed into cleaned acid-washed polypropylene bags, and immediately frozen.

2.3. Mercury Concentration Analyses. Samples were shipped frozen to the University of Michigan, where they were thawed. Water samples were oxidized with concentrated $\mathrm{BrCl}$ to $1 \%$ by volume. All mercury analyses were performed by cold vapor atomic absorption spectroscopy using an automated
Nippon Instruments MA-2 mercury analyzer. $\mathrm{BrCl}$ in water samples was reduced with $\mathrm{NH}_{2} \mathrm{OH}$ and then $\mathrm{Hg}$ (II) was reduced with $\mathrm{SnCl}_{2}$ to $\mathrm{Hg}(0)$, concentrated on a gold trap, and released by heating to the detector for analysis. The detection limit for water samples was $0.2 \mathrm{ng} / \mathrm{L}$, and the analytical uncertainty was $\pm 5 \%$ for concentration measurements above 1 ng/L. Field and laboratory procedural blanks were collected and analyzed to determine the potential for contamination of samples. Blank checks using $18 \mathrm{M} \Omega$ deionized water placed in sample bottles in the field yielded mercury concentrations from 1.1 to $2.1 \mathrm{ng} / \mathrm{L}$, while blanks from snow collection trays ranged from 1.2 to $3.4 \mathrm{ng} / \mathrm{L}$. These blank values are very low compared to the values measured in most samples. In the lowest concentration samples measured, however, the blank is as high as $12 \%$ of the $\mathrm{Hg}$ in the sample. The spatial variability of mercury deposition to snow is not well-known. When sampling snow in duplicate we collected two samples $\sim 0.5 \mathrm{~m}$ apart. During previous sampling campaigns we sampled in triplicate with $\sim 0.5 \mathrm{~m}$ lateral spacing between samples. The percent relative standard deviation (\%RSD) of the mercury concentrations measured from duplicate samples averaged $9.5 \%$. On all of our data figures the \%RSD is smaller than the size of the plotted symbols. Peat samples were sectioned into 1 $\mathrm{cm}$ slices in the laboratory, and then both peat samples and the vegetation mat above them were freeze-dried and ground to a powder using a mortar and pestle. Subsamples were combusted in air in a Nippon Instruments MA-2 mercury analyzer. Solid sample detection limits were $0.2 \mathrm{ng} / \mathrm{g}$ with an uncertainty of $\pm 5 \%$.

2.4. Mercury Isotope Ratio Measurements. After $\mathrm{Hg}$ concentration analysis, water and snow samples with sufficient $\mathrm{Hg}$ for isotopic analysis (i.e., $>8 \mathrm{ng}$ ) were concentrated into acidic $1 \% \mathrm{KMnO}_{4}(\mathrm{w} / \mathrm{w})$ solutions as follows. Each sample was poured into a $2 \mathrm{~L}$ Pyrex bottle, and $0.3 \mathrm{~mL}$ of $30 \%$ $\mathrm{NH}_{2} \mathrm{OH} \mathrm{HCl}(\mathrm{w} / \mathrm{v})$ was added and allowed to react for 30 min. A peristaltic pump and $\mathrm{Hg}$-free tubing were then used to add $100 \mathrm{~mL}$ of $5 \% \mathrm{SnCl}_{2}(\mathrm{w} / \mathrm{v})$ to the solution at a rate of 10 $\mathrm{mL} / \mathrm{min}$. Mercury-free air was pulled through the sample and carried the resulting GEM into the $\mathrm{KMnO}_{4}$ trapping solution at a rate of $0.7 \mathrm{~L} / \mathrm{min}$ for $4 \mathrm{~h}$. Procedural standards $(25$ to 50 ng of SRM 3133 in $1 \% \mathrm{BrCl}$ ) and blanks were processed in the same manner. Mercury in these standards was consistently recovered in the final solutions (mean recovery $=91 \pm 6 \%$ ). The small amount of $\mathrm{Hg}$ measured in the procedural blanks (mean $=0.22 \pm 0.12 \mathrm{ng}$ per blank, $n=3$ ) was attributable to the $\mathrm{KMnO}_{4}$ solutions.

The isotopic composition of $\mathrm{Hg}$ in peat samples was measured by combusting the samples in oxygen in a two-stage furnace and then trapping the released $\mathrm{Hg}(0)$ in an oxidizing acidic $1 \% \mathrm{KMnO}_{4}(\mathrm{w} / \mathrm{w})$ solution. $\mathrm{KMnO}_{4}$ solutions containing $\mathrm{Hg}$ from water, snow, peat, and vegetation samples were adjusted to a concentration of $5 \mathrm{ng} / \mathrm{g}$ and measured using continuous-flow cold vapor generation multicollector inductively coupled plasma mass spectrometry (MC-ICP-MS) with thallium mass bias correction and sample-standard bracketing to $5 \mathrm{ng} / \mathrm{g}$ NIST 3133 standard solutions. Analytical results and uncertainties for internal and external standards are given in Table 1 and agree with literature values. ${ }^{29}$ Additional details of $\mathrm{Hg}$ isotopic analyses have been published elsewhere. ${ }^{31,37,41}$

\section{RESULTS AND DISCUSSION}

There is a variety of different types of samples from our study site near Utqiagvik that we analyzed for $\mathrm{Hg}$ isotope ratios 
including $\delta^{202} \mathrm{Hg}$ (MDF) and $\Delta^{199} \mathrm{Hg}$ (MIF) and that are enclosed in ovals on Figure 2. Some of these analyses were
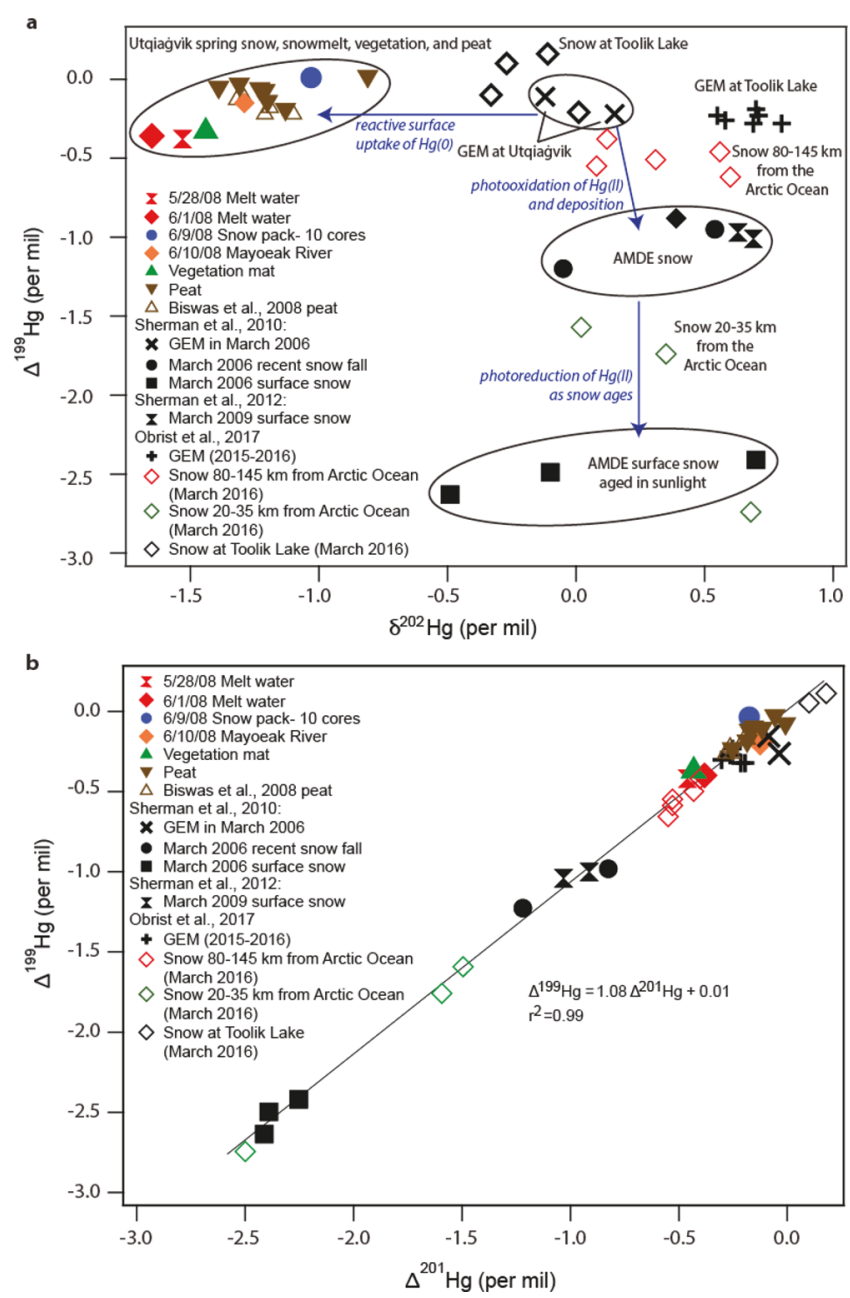

Figure 2. $\mathrm{Hg}$ stable isotope composition of ecosystem sources and sinks including snow and GEM from three related studies ${ }^{12,13,31}$ and, from this study, 2008 snowmelt, the surface vegetation mat, and peat from our soil core and from another study in the area. ${ }^{39}$ (a) Massindependent $\left(\Delta^{199} \mathrm{Hg}\right)$ and mass-dependent $\left(\delta^{202} \mathrm{Hg}\right)$ mercury isotope values with ovals to identify some sample-type groupings and (b) mass-independent $\mathrm{Hg}$ isotopic compositions $\left(\Delta^{199} \mathrm{Hg}\right.$ and $\left.\Delta^{201} \mathrm{Hg}\right)$.

presented in previous publications by us. ${ }^{12,31,39}$ We also include analyses of GEM and snow from Obrist et al. ${ }^{13}$ from Toolik Lake ( $200 \mathrm{~km}$ south of the Arctic Coast) and along a transect from Toolik to the Arctic Coast, to provide additional analyses of GEM and snow on the north slope of Alaska (these samples are not enclosed in ovals on Figure 2). Samples analyzed by us from near Utqiagivik include: GEM (March), fresh snowfall (March), aged snow (March), integrated snowpack (May/June), snowpack meltwater (May/June), surface runoff during the melt period (June), surface vegetation mat (October), and a $150 \mathrm{~cm}$ profile of peat (Oct). Snow samples collected in 2006 and 2009, for which we also have $\mathrm{Hg}$ stable isotope measurements, range in total $\mathrm{Hg}$ concentrations from 69 to $416 \mathrm{ng} / \mathrm{L}$. These $\mathrm{Hg}$ concentrations are more than 30 times greater than the highest concentration reported from inland snow at Toolik Lake. ${ }^{13}$ Initial meltwater at the base of the snowpack (32.4 ng/L), meltwater on June 1 (25.1 ng/L), the integrated snowpack (10.2 ng/L), and the Mayoeak River (9.2 $\mathrm{ng} / \mathrm{L})$ all yield lower concentrations.

Among the samples we analyzed from Utqiagvik there is a wide range in both $\delta^{202} \mathrm{Hg}$ and $\Delta^{199} \mathrm{Hg}$ values. Relative to other sample types, GEM has high $\delta^{202} \mathrm{Hg}$ (near zero) and high $\Delta{ }^{199} \mathrm{Hg}$ (averaging $-0.1 \%$ ). March fresh snowfall collected during active AMDEs at Utqiagvik has high $\delta^{202} \mathrm{Hg}$ similar to GEM but with much lower $\Delta^{199} \mathrm{Hg}$ averaging $-1.1 \%$. GEM measured at Toolik Lake has a $\sim 0.7 \%$ greater $\delta^{202} \mathrm{Hg}$ value than GEM measured at Utqiagvik, and the two populations are statistically significantly different (using an analysis of means with a significance level $(\alpha)$ of 0.05$)$. The $\Delta^{199} \mathrm{Hg}$ values at both sites are statistically significantly indistinguishable but the two Utqiagvik samples are slightly higher than those from Toolik Lake. Aged snow from the March AMDE season has $\delta^{202} \mathrm{Hg}$ similar to fresh snow but with a much lower $\Delta^{199} \mathrm{Hg}$ averaging $-2.5 \%$. Finally, there is a large contrast between the isotopic composition of $\mathrm{Hg}$ in all of the March snow samples from Utqiagvik and the isotopic composition of $\mathrm{Hg}$ in all of the May/June snowpack and snowmelt samples (Figure 2a).

All of the snowmelt samples from Utqiagivik display MDF and MIF similar to the June snowpack. May/June snowpack and meltwaters have $\Delta^{199} \mathrm{Hg}$ near zero (average $-0.16 \%$ ), like GEM, but have $\delta^{202} \mathrm{Hg} 1.0$ to $1.5 \%$ lower than GEM and March snow. On a $\Delta^{199} \mathrm{Hg}$ versus $\Delta^{201} \mathrm{Hg}$ plot the samples fall on a line with a slope of $\sim 1$, indicative of photochemical reduction of $\mathrm{Hg}$ (II) (Figure $2 \mathrm{~b}$ ). $\mathrm{Hg}$ in the vegetation mat and the upper $5 \mathrm{~cm}$ of peat has $\delta^{202} \mathrm{Hg}, \Delta^{199} \mathrm{Hg}$, and $\Delta^{199} \mathrm{Hg}$ values that overlap with values for the May/June snow and snowpack, meltwater, and Mayoeak River runoff samples that we ascribe to $\mathrm{Hg}$ released by melting of the seasonal snowpack.

The peat samples provide a long-term archive of the $\mathrm{Hg}$ stable isotope values deposited to the study area during all seasons. Figure $3 \mathrm{a}$ includes $\mathrm{Hg}$ concentrations for the peat cores, and the $\mathrm{Hg}$ stable isotope values are provided in Figure $3 \mathrm{~b}$. In each of two cores the surface vegetation mat $\mathrm{Hg}$ concentrations are $\sim 3$ times that of the peat soils below. In earlier work from similar samples at this research site nearsurface peat samples with elevated $\mathrm{Hg}$ concentrations were identified as of "modern age", ${ }^{39}$ but neither that study nor this study have age dates to confirm this. $\delta^{202} \mathrm{Hg}$ and $\Delta^{199} \mathrm{Hg}$ values of the surface vegetation are slightly lower than that of the seasonally thawed soils and permafrost peat. On the basis of a comparison of means with a significance level $(\alpha)$ of 0.05 the $\delta^{202} \mathrm{Hg}$ values of the vegetation and peat are not statistically different, but the $\Delta^{199} \mathrm{Hg}$ values of the vegetation and peat are statistically different. The vegetation and peat $\Delta^{199} \mathrm{Hg}$ and $\delta^{202} \mathrm{Hg}$ values are similar to the snowmelt and runoff values as well as what would be expected for GEM deposition to vegetation during the summer. ${ }^{17,32,33}$ Previous studies have reported that at least $70 \%$ of the $\mathrm{Hg}$ deposition is attributable to gaseous elemental $\mathrm{Hg}$ at Arctic inland ${ }^{17}$ and coastal ${ }^{21}$ locations. It is clear from the results of this study that the end of winter $\mathrm{Hg}$ deposition to the tundra from melting of the seasonal snowpack has a dominantly atmospheric GEM $\Delta^{199} \mathrm{Hg}$ signature. The $\delta^{202} \mathrm{Hg}$ value of snowmelt is consistent with reactive surface uptake of GEM and is isotopically similar to what would be expected from reactive surface uptake onto vegetation surfaces or the snowpack.

Our interpretation of the contrasting $\mathrm{Hg}$ isotope ratios among the five different types of samples we analyzed near Utqiagvik (Figures 2 and 3) is based on current knowledge of 

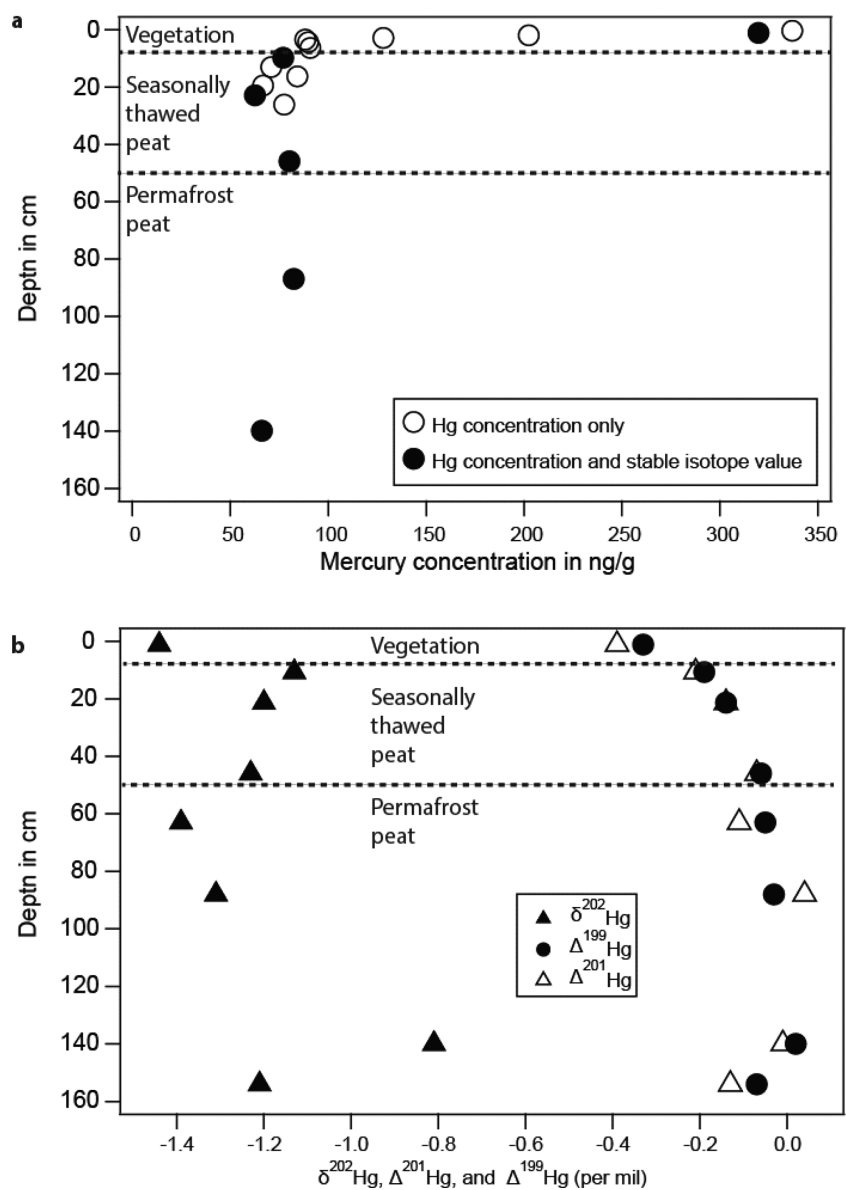

Figure 3. Mercury concentrations and mercury stable isotope values from a late summer sampling event representing the seasonally thawed layer above permafrost (open circles in (a)) and from a $1.5 \mathrm{~m}$ core collected in the late spring when the ground was frozen (closed circles in (a) and all symbols in (b)).

the $\mathrm{Hg}$ isotope fractionations known to occur during important $\mathrm{Hg}$ transformations in the atmosphere and during deposition to the land surface. ${ }^{29,42}$ The isotopic composition of GEM in the Arctic near Utqiagivik is similar to values measured at numerous lower latitude locations ${ }^{32}$ and at Toolik Lake. ${ }^{13}$ For example, the GEM $\Delta^{199} \mathrm{Hg}$ values for Toolik Lake and Utqiagvik are within $0.25 \%$ of one another, while GEM $\delta^{202} \mathrm{Hg}$ values for Toolik Lake and Utqiagvik are within $1 \%$ of one another. GEM values for $\Delta^{199} \mathrm{Hg}$ and $\delta^{202} \mathrm{Hg}$ measured in the Great Lakes Region ${ }^{32}$ also fall within the range for Toolik Lake and Utqiagvik. During March AMDEs, $\mathrm{Hg}(0)$ is photochemically oxidized in the lower atmosphere and deposited to snow and ice surfaces. ${ }^{9,36,43}$ We suggest, on the basis of previous studies, that this snow has similar $\delta^{202} \mathrm{Hg}$ as GEM but with lower $\Delta^{199} \mathrm{Hg}$ than GEM due to fractionation from photochemical oxidation of $\mathrm{Hg}(0)$ to $\mathrm{Hg}(\mathrm{II})$ in the atmosphere. $^{12,40}$ Once this $\mathrm{Hg}$ (II) is deposited to the snowpack, some of the $\mathrm{Hg}$ (II) is photochemically reduced as the snow ages, further driving the remaining $\mathrm{Hg}$ (II) in surface snow to the progressively lower $\Delta^{199} \mathrm{Hg}$ values we observed for the surface of drifted snow in March (prior to initiation of the melt; Figure 2a). The average $\Delta^{199} \mathrm{Hg}$ of GEM we measured is $-0.16 \%$, and the average of fresh snow we sampled had $\Delta^{199} \mathrm{Hg}$ of ca. $-1.04 \%$. The surface of aged snow had even lower $\Delta^{199} \mathrm{Hg}$ of ca. $-2.5 \%$. These three different sample types yield statistically different $\Delta^{199} \mathrm{Hg}$ values based on an analysis of means with a significance level $(\alpha)$ of 0.05 . All of the snow samples collected during the spring AMDE season had high $\delta^{202} \mathrm{Hg}$ values between -0.5 and 0.7 . In striking contrast, May and June snow cores (representing periods when AMDEs were no longer active), meltwaters, the vegetation mat, and near-surface peat samples have much lower $\delta^{202} \mathrm{Hg}$ values of -1.3 and $-1.1 \%$, but $\Delta^{199} \mathrm{Hg}$ values near zeromatching that of GEM. As mentioned above, the vegetation, peat, and spring AMDE snow from Utqiagivik have $\Delta^{199} \mathrm{Hg}$ values in the same range as soils and vegetation from Toolik Lake. $^{13}$

Obrist et al. $(2017)^{13}$ concluded that the shift in $\delta^{202} \mathrm{Hg}$ to lower values in soils and vegetation compared to GEM was caused by isotopic fractionation during reactive surface uptake of GEM by vegetation by a process that was documented previously. ${ }^{32}$ This interpretation is plausible for the Toolik Lake study, but it cannot explain the offset in $\delta^{202} \mathrm{Hg}$ between GEM and May/June snow and meltwater that has not come in contact with vegetation or soil that we observe in Utqiagivik. We suggest instead that GEM is being oxidized and retained within the snowpack at Utqiagvik through a reactive surface uptake process mediated by halogens ${ }^{14,15,17,18,25,42,44}$ and/or by organic matter, which is known to be present in Arctic snow. ${ }^{24}$ This is somewhat analogous to GEM entering the stomata of leaves and becoming oxidized by organic matter within the foliage. ${ }^{32}$ During the summer months GEM may also be oxidized and fractionated by vegetation and soil at Utqiagvik by the same process observed at Toolik Lake. ${ }^{13}$

Thus, we identified one characteristic $\mathrm{Hg}$ isotope signature for $\mathrm{Hg}$ deposited during AMDEs (with high $\delta^{202} \mathrm{Hg}$ and a range of $\Delta^{199} \mathrm{Hg}$ values depending on the degree of photoreduction and release of $\mathrm{Hg}(0)$ from the snowpack) and another, which we hypothesize to be for $\mathrm{Hg}$ deposited by GEM within the snowpack (with low $\delta^{202} \mathrm{Hg}$ and high $\Delta^{199} \mathrm{Hg}$ ). Snow deposited during the March AMDE season has a similar $\delta^{202} \mathrm{Hg}$ value as atmospheric GEM. The snowpack during the May/June snowmelt season has a highly contrasting $\mathrm{Hg}$ isotopic signature compared to the March snowpack, and it is shifted by $\sim 2 \%$ o to lower $\delta^{202} \mathrm{Hg}$ by oxidation of GEM in the snowpack. Since the isotopic composition of meltwater overlaps that of the snowpack we conclude that virtually all of the $\mathrm{Hg}$ released in meltwater during the spring melt is derived from $\mathrm{Hg}$ that originated as GEM and was deposited to the snowpack by oxidation and reactive surface uptake within the snowpack. In contrast, $\mathrm{Hg}$ deposited to snow crystals during AMDEs at high concentrations is largely photochemically reduced and released back to the atmosphere as GEM, leaving low concentrations (ca. fourfold lower; see Table 1) of residual $\mathrm{Hg}(\mathrm{II})$ with a similar $\delta^{202} \mathrm{Hg}$ as GEM, but a much lower $\Delta^{199} \mathrm{Hg}$, as has been observed for AMDEs following photoreduction in aged snow. ${ }^{31}$ Because the $\mathrm{Hg}(\mathrm{II})$ is deposited within the snowpack its exposure to sunlight is dependent on the light penetration depth, often quantified by the e-folding depth, which is the depth at which irradiance is attenuated to $37 \%$ of its initial value. This has been measured at Utqiagivik to be between 3 and $18 \mathrm{~cm}$ depending on the snow type and wavelength. ${ }^{45}$ As such, we would expect the oxidation of $\mathrm{Hg}$ in the snowpack to be dominated by processes occurring in the upper $\sim 15-20 \mathrm{~cm}^{18}$ In late spring, during snowmelt, as the snowpack degrades and shrinks, the penetration depth of sunlight likely increases as a percentage of the total snowpack depth because of an increase in grain size. ${ }^{46}$ 
Previous studies have suggested that $\sim 75 \%$ of the $\mathrm{Hg}$ deposited during AMDEs is photochemically reduced from snow and re-emitted to the atmosphere. ${ }^{21,31}$ A small amount of AMDE-derived $\mathrm{Hg}$ may be present in snowmelt, but based on the average $\Delta^{199} \mathrm{Hg}$ of GEM $\left(-0.16 \%\right.$ ), the average $\Delta^{199} \mathrm{Hg}$ of AMDE derived $\mathrm{Hg}\left(-1.04 \%\right.$ ), and the $\Delta^{199} \mathrm{Hg}$ of spring snowmelt $(-0.37 \%$ ), we calculate from our data, using a simple mixing model, that it comprises a maximum of $24 \%$ of the total $\mathrm{Hg}$. The proportion of AMDE $\mathrm{Hg}$ in snowmelt could be as low as 9\% if the AMDE $\mathrm{Hg}$ endmember is taken to be $\mathrm{Hg}$ in AMDE-deposited snow that has been aged in sunlight, lowering its $\Delta^{199} \mathrm{Hg}$ to an average of $-2.51 \%$ (Figure $2 \mathrm{a}$ ). Thus the dominant source of the $\mathrm{Hg}$ in our spring melt samples is GEM that has been oxidized by reactive halogens and/or organics within the snowpack. Enhanced concentrations of GEM in the arctic coastal atmosphere have been observed at the start of the snowmelt period. ${ }^{9}$ The enhanced GEM and its oxidation and retention in the snowpack provides an explanation for the higher $\mathrm{Hg}$ concentrations in coastal snow, snow on sea ice, and snowmelt compared to inland locations on the Arctic Coast.

Projected future warming in the Arctic will produce a more dynamic sea ice regime. This includes a decline in sea ice extent, an increasing fraction of first year ice, and an increasing areal extent of open sea-ice leads. ${ }^{47,48}$ These conditions are expected to provide a greater pool of reactive halogens to coastal snowpacks and this may promote GEM oxidation and deposition into the snowpack. Further research, in both laboratory and field settings, is needed to explore the links between snowpack halogens and $\mathrm{Hg}$ oxidation and retention in the snowpack. Additionally, there is an increasing need to better account for the spatial and temporal variability of $\mathrm{Hg}$ deposition and oxidation and the role of AMDEs and halogenrich snow in $\mathrm{Hg}$ deposition across the entire Arctic region.

\section{ACKNOWLEDGMENTS}

This work was funded by the U.S. National Science Foundation Office of Polar Programs Grant Nos. ARC0435989 (U.S. Army Cold Regions Research and Engineering Laboratory) and ARC-0435893 (Univ. of Michigan). Extensive logistical support was provided by the Barrow Arctic Science Consortium, and their assistance is greatly appreciated. Numerous colleagues assisted with sample collection and hearty discussions of the Arctic mercury cycle, particularly M. Sturm, C. Polashenski, A. Steffen, and L. Sherman. We thank anonymous reviewers for their comments on earlier versions of the manuscript.

\section{REFERENCES}

(1) Douglas, T. A.; Sturm, M.; Simpson, W. R.; Brooks, S.; Lindberg, S. E.; Perovich, D. K. Elevated mercury measured in snow and frost flowers near arctic sea ice leads. Geophys. Res. Lett. 2005, 32, L04502.
(2) Domine, F; Gallet, J. C.; Barret, M; Houdier, S; Voisin, D; Douglas, T. A.; Blum, J. D.; Beine, H. J.; Anastasio, C; Bréon, F. M. The specific surface area and chemical composition of diamond dust near Barrow, Alaska. J. Geophys. Res.: Atmos. 2011, 116 (D14), na DOI: 10.1029/2011JD016162.

(3) Morel, F. M. M.; Kraepiel, A. M. L.; Amyot, M. The chemical cycle and bioaccumulation of mercury. Annu. Rev. Ecol. Syst. 1998, 29, $543-566$.

(4) Grigal, D. F. Mercury sequestration in forests and peatlands. J. Environ. Qual. 2003, 32 (2), 393-405.

(5) Jæger, I.; Hop, H.; Gabrielsen, G. W. Biomagnification of mercury in selected species from an Arctic marine food web in Svalbard. Sci. Total Environ. 2009, 407 (16), 4744-4751.

(6) Wheatley, B.; Wheatley, M. Methylmercury and the health of indigenous peoples: a risk management challenge for physical and social sciences and for public health policy. Sci. Total Environ. 2000, $259,23-30$.

(7) Kane, D. L.; Hinzman, L. D.; McNamara, J. P.; Benson, C. S.; et al. An overview of a nested watershed study in Arctic Alaska. Nord. Hydrol. 2000, 31 (4-5), 245-266.

(8) Schroeder, W. H.; Anlauf, K. G.; Barrie, L. A.; Lu, J. Y.; Steffen, A.; Schneeberger, D. R.; Berg, T. Arctic springtime depletion of mercury. Nature 1998, 394, 331.

(9) Lindberg, S. E.; Brooks, S.; Lin, C.-J.; Scott, K. J.; Landis, M. S.; Stevens, R. K.; Goodsite, M.; Richter, A. Dynamic oxidation of gaseous mercury in the Arctic troposphere at Polar sunrise. Environ. Sci. Technol. 2002, 36, 1245-1256.

(10) Steffen, A.; Douglas, T.; Amyot, M.; Ariya, P.; Aspmo, K.; Berg, T.; Bottenheim, J.; Brooks, S.; Cobbett, F.; Dastoor, A.; Dommergue, A.; et al. A synthesis of atmospheric mercury depletion event chemistry in the atmosphere and snow. Atmos. Chem. Phys. 2008, 8 (6), 1445-82.

(11) Douglas, T. A.; Sturm, M.; Simpson, W. R.; Blum, J. D.; Alvarez-Aviles, L.; Keeler, G. J.; Perovich, D. K.; Biswas, A.; Johnson, $\mathrm{K}$. Influence of snow and ice crystal formation and accumulation on mercury deposition to the Arctic. Environ. Sci. Technol. 2008, 42 (5), $1542-1551$.

(12) Sherman, L. S.; Blum, J. D.; Douglas, T. A.; Steffen, A. Frost flowers growing in the Arctic ocean-atmosphere-sea ice-snow interface: Part 2: Mercury exchange between the atmosphere, snow and frost flowers. J. Geophys. Res. Atmos. 2012, 117, na.

(13) Obrist, D.; Agnan, Y.; Jiskra, M.; Olson, C. L.; Colegrove, D. P.; Hueber, J.; Moore, C. W.; Sonke, J. E.; Helmig, D. Tundra uptake of atmospheric elemental mercury drives Arctic mercury pollution. Nature 2017, 547 (7662), 201-204.

(14) Simpson, W. R.; Alvarez-Aviles, L.; Douglas, T. A.; Sturm, M.; Domine, F. Halogens in the coastal snow pack near Barrow, Alaska: Evidence for active bromine air-snow chemistry during springtime. Geophysical research letters. 2005, 32 (4), na.

(15) Abbatt, J. P.; Thomas, J. L.; Abrahamsson, K.; Boxe, C.; Granfors, A.; Jones, A. E.; King, M. D.; Saiz-Lopez, A.; Shepson, P. B.; Sodeau, J.; Toohey, D. W. Halogen activation via interactions with environmental ice and snow in the polar lower troposphere and other regions. Atmos. Chem. Phys. 2012, 12 (14), 6237-71.

(16) Amyot, M.; Morel, F. M.; Ariya, P. A. Dark oxidation of dissolved and liquid elemental mercury in aquatic environments. Environ. Sci. Technol. 2005, 39 (1), 110-4.

(17) Simpson, W. R.; Carlson, D.; Hönninger, G.; Douglas, T. A.; Sturm, M.; Perovich, D.; Platt, U. First-year sea-ice contact predicts bromine monoxide $(\mathrm{BrO})$ levels at Barrow, Alaska better than potential frost flower contact. Atmos. Chem. Phys. 2007, 7 (3), 621-7.

(18) Pratt, K. A.; Custard, K. D.; Shepson, P. B.; Douglas, T. A.; Pöhler, D.; General, S.; Zielcke, J.; Simpson, W. R.; Platt, U.; Tanner, D. J.; Huey, L. G. Photochemical production of molecular bromine in Arctic surface snowpacks. Nat. Geosci. 2013, 6 (5), 351-356.

(19) Spolaor, A.; Vallelonga, P.; Gabrieli, J.; Martma, T.; Björkman, M. P.; Isaksson, E.; Cozzi, G.; Turetta, C.; Kjær, H. A.; Curran, M. A.; Moy, A. D. Seasonality of halogen deposition in polar snow and ice. Atmos. Chem. Phys. 2014, 14 (18), 9613-9622. 
(20) Dommergue, A.; Ferrari, C. P.; Gauchard, P.-A.; Boutron, C. F.; Poissant, L.; Pilote, M.; Jitaru, P.; Adams, F. C. The fate of mercury species in a sub-arctic snowpack during snowmelt. Geophys. Res. Lett. 2003, 30, 1621.

(21) Douglas, T. A.; Sturm, M.; Blum, J. D.; Polashenski, C.; Stuefer, S.; Hiemstra, C. A.; Steffen, A.; Filhol, S.; Prevost, R. A pulse of mercury and major ions in snowmelt runoff from a small Arctic Alaska watershed. Environ. Sci. Technol. 2017, 51, 11145.

(22) Douglas, T. A.; Loseto, L. L.; Macdonald, R. W.; Outridge, P.; Dommergue, A.; Poulain, A.; Amyot, M.; Barkay, T.; Berg, T.; Chételat, J.; Constant, P.; et al. The fate of mercury in Arctic terrestrial and aquatic ecosystems, a review. Environ. Chem. 2012, 9 (4), 321-55.

(23) Kirk, J. L.; Lehnherr, I.; Andersson, M.; Braune, B. M.; Chan, L.; Dastoor, A. P.; Durnford, D.; Gleason, A. L.; Loseto, L. L.; Steffen, A.; St Louis, V. L. Mercury in Arctic marine ecosystems: Sources, pathways and exposure. Environ. Res. 2012, 119, 64-87.

(24) Bartels-Rausch, T.; Krysztofiak, G.; Bernhard, A.; Schläppi, M.; Schwikowski, M.; Ammann, M. Photoinduced reduction of divalent mercury in ice by organic matter. Chemosphere 2011, 82 (2), 199203.

(25) Krnavek, L.; Simpson, W. R.; Carlson, D.; Domine, F.; Douglas, T. A.; Sturm, M. The chemical composition of surface snow in the Arctic: Examining marine, terrestrial, and atmospheric influences. Atmos. Environ. 2012, 50 (50), 349-359.

(26) Snyder-Conn, E.; Garbarino, J. R.; Hoffman, G. L.; Oelkers, A. Soluble Trace Elements and Total Mercury in Arctic Alaskan Snow. Arctic 1997, 50, 201-215.

(27) Douglas, T.; Sturm, M. Arctic haze, mercury and the chemical composition of snow across northwestern Alaska. Atmos. Environ. 2004, 38 (6), 805-820.

(28) Schuster, P. F.; Shanley, J. B.; Marvin-Dipasquale, M.; Reddy, M. M.; Aiken, G. R.; Roth, D. A.; Taylor, H. E.; Krabbenhoft, D. P.; DeWild, J. F. Mercury and organic carbon dynamics during runoff episodes from a northeastern USA watershed. Water, Air, Soil Pollut. 2007, 187 (1-4), 89-108.

(29) Blum, J. D.; Sherman, L. S.; Johnson, M. W. Mercury Isotopes in Earth and Environmental Sciences. In Annual Review of Earth and Planetary Sciences, Jeanloz, R., Ed.; 2014; Vol. 42, pp 249-269. DOI: 10.1146/annurev-earth-050212-124107.

(30) Bergquist, B. A.; Blum, J. D. Mass-dependent and-independent fractionation of $\mathrm{Hg}$ isotopes by photoreduction in aquatic systems. Science 2007, 318 (5849), 417-20.

(31) Sherman, L. S.; Blum, J. D.; Johnson, K. P.; Keeler, G. J.; Barres, J. A.; Douglas, T. A. Mass-independent fractionation of mercury isotopes in Arctic snow driven by sunlight. Nat. Geosci. 2010, 3 (3), $173-7$.

(32) Demers, J. D.; Blum, J. D.; Zak, D. R. Mercury isotopes in a forested ecosystem: Implications for air-surface exchange dynamics and the global mercury cycle. Global Biogeochemical Cycles. 2013, 27 (1), 222-38.

(33) Jiskra, M.; Wiederhold, J. G.; Skyllberg, U.; Kronberg, R. M.; Kretzschmar, R. Source tracing of natural organic matter bound mercury in boreal forest runoff with mercury stable isotopes. Environmental Science: Processes \& Impacts. 2017, 19 (10), 1235-48.

(34) Poulain, A. J.; Garcia, E.; Amyot, M.; Campbell, P. G. C.; Ariya, P. Mercury distribution, partitioning and speciation in coastal vs. inland high arctic snow. Geochim. Cosmochim. Acta 2007, 71 (14), 3419-3431.

(35) Steffen, A.; Bottenheim, J.; Cole, A.; Douglas, T. A.; Ebinghaus, R.; Friess, U.; Netcheva, S.; Nghiem, S.; Sihler, H.; Staebler, R. Atmospheric mercury over sea ice during the OASIS-2009 campaign. Atmos. Chem. Phys. 2013, 13, 7007-7021.

(36) Johnson, K. P.; Blum, J. D.; Keeler, G. J.; Douglas, T. A. Investigation of the deposition and emission of mercury in arctic snow during an atmospheric mercury depletion event. J. Geophys. Res. Atmos. 2008, 113 (D17). DOI: 10.1029/2008JD009893

(37) Sellmann, P. V.; Brown, J.; Lewellen, R. I.; McKim, H.; Merry, C. The classification and geomorphic implication of thaw lakes on the
Arctic Coastal Plain, Alaska; Research report 344; U.S. Army CRREL: Hanover, NH, 1975.

(38) Hubbard, S. S.; Gangodagamage, C.; Dafflon, B.; Wainwright, H.; Peterson, J.; Gusmeroli, A.; Ulrich, C.; Wu, Y.; Wilson, C.; Rowland, J.; Tweedie, C.; et al. Quantifying and relating land-surface and subsurface variability in permafrost environments using LiDAR and surface geophysical datasets. Hydrogeol. J. 2013, 21 (1), 149-69.

(39) Biswas, A.; Blum, J. D.; Bergquist, B. A.; Keeler, G. J.; Xie, Z. Natural mercury isotope variation in coal deposits and organic soils. Environ. Sci. Technol. 2008, 42 (22), 8303-9.

(40) Blum, J. D.; Bergquist, B. A. Reporting of variations in the natural isotopic composition of mercury. Anal. Bioanal. Chem. 2007, 388 (2), 353-9.

(41) Blum, J. D.; Johnson, M. W. Recent developments in mercury stable isotope analysis. Rev. Mineral. Geochem. 2017, 82 (1), 733-57.

(42) Sun, G.; Sommar, J.; Feng, X.; Lin, C. J.; Ge, M.; Wang, W.; Yin, R.; Fu, X.; Shang, L. Mass-dependent and-independent fractionation of mercury isotope during gas-phase oxidation of elemental mercury vapor by atomic $\mathrm{Cl}$ and $\mathrm{Br}$. Environ. Sci. Technol. 2016, 50 (17), 9232-41.

(43) Ariya, P. A.; Khalizov, A.; Gidas, A. Reactions of gaseous mercury with atomic and molecular halogens: Kinetics, product studies, and atmospheric Implications. J. Phys. Chem. A 2002, 106, $7310-7320$.

(44) Moore, C. W.; Obrist, D.; Steffen, A.; Staebler, R.; Douglas, T. A.; Nghiem, S. V.; et al. Sea ice lead-induced convective forcing and ozone in the Arctic boundary layer. Nature 2014, 506 (7486), 81-84.

(45) France, J. L., Reay, H. J., King, M. D., Voisin, D., Jacobi, H. W., Domine, F., Beine, H., Anastasio, C., MacArthur, A., Lee-Taylor, J. Hydroxyl radical and $\mathrm{NOx}$ production rates, black carbon concentrations and light-absorbing impurities in snow from field measurements of light penetration and nadir reflectivity of onshore and offshore coastal Alaskan snow. J. Geophys. Res.: Atmos.. $2012 \mathrm{Jul}$ 27;117(D14). DOI: 10.1029/2011JD016639

(46) Libois, Q.; Picard, G.; France, J. L.; Arnaud, L.; Dumont, M.; Carmagnola, C. M.; King, M. D. Influence of grain shape on light penetration in snow. Cryosphere. 2013, 7, 1803-1818.

(47) Maslanik, J. A., Fowler, C., Stroeve, J., Drobot, S., Zwally, J., Yi, D., Emery, W. A younger, thinner Arctic ice cover: Increased potential for rapid, extensive sea-ice loss. Geophys. Res. Lett. 2007 Dec 1;34(24). DOI: $10.1029 / 2007$ GL032043

(48) Lindsay, R.; Schweiger, A. Arctic sea ice thickness loss determined using subsurface, aircraft, and satellite observations. Cryosphere. 2015, 9 (1), 269-83. 


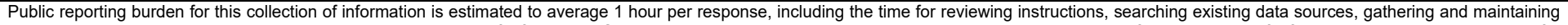

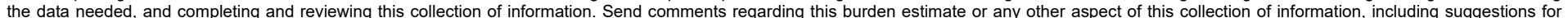

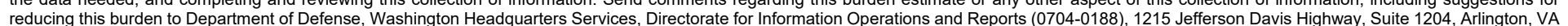

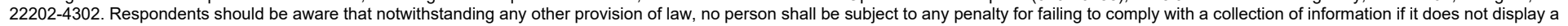
currently valid OMB control number. PLEASE DO NOT RETURN YOUR FORM TO THE ABOVE ADDRESS.
1. REPORT DATE (DD-MM-YYYY)
June 2021

\section{REPORT TYPE}
Final

\section{TITLE AND SUBTITLE}

Mercury Isotopes Reveal Atmospheric Gaseous Mercury Deposition Directly to the Arctic Coastal Snowpack

\section{AUTHOR(S)}

Thomas A. Douglas and Joel D. Blum
3. DATES COVERED (From - To)

5a. CONTRACT NUMBER

5b. GRANT NUMBERS

ARC-0435989 and ARC-0435893

5c. PROGRAM ELEMENT NUMBER

5d. PROJECT NUMBER

5e. TASK NUMBER

5f. WORK UNIT NUMBER

8. PERFORMING ORGANIZATION REPORT NUMBER

University of Michigan Dept of Earth \& Env Sciences 1100 N University Avenue

Ann Arbor, MI 48109

ERDC/CRREL MP-21-5

Cold Regions Research and Engineering Laboratory

72 Lyme Road

Hanover, NH 07552

9. SPONSORING / MONITORING AGENCY NAME(S) AND ADDRESS(ES)

10. SPONSOR/MONITOR'S ACRONYM(S)

U.S. National Science Foundation

Office of Polar Programs

Alexandria, VA 22314

11. SPONSOR/MONITOR'S REPORT NUMBER(S)

\section{DISTRIBUTION / AVAILABILITY STATEMENT}

Approved for public release; distribution is unlimited.

\section{SUPPLEMENTARY NOTES}

Originally published by the American Chemical Society in the Environmental Science and Technology Letters on 7 March 2019.

\section{ABSTRACT}

Springtime atmospheric mercury depletion events (AMDEs) lead to snow with elevated mercury concentrations ( $>200 \mathrm{ng} \mathrm{Hg} / \mathrm{L}$ ) in the Arctic and Antarctic. During AMDEs gaseous elemental mercury (GEM) is photochemically oxidized by halogens to reactive gaseous mercury which is deposited to the snowpack. This reactive mercury is either photochemically reduced back to GEM and reemitted to the atmosphere or remains in the snowpack until spring snowmelt. GEM is also deposited to the snowpack and tundra vegetation by reactive surface uptake (dry deposition) from the atmosphere. There is little consensus on the proportion of AMDEsourced $\mathrm{Hg}$ versus $\mathrm{Hg}$ from dry deposition that is released in spring runoff. We used mercury stable isotope measurements of GEM, snowfall, snowpack, snowmelt, surface water, vegetation, and peat from a northern Alaska coastal watershed to quantify Hg sources. Although high $\mathrm{Hg}$ concentrations are deposited to the snowpack during AMDEs, we estimate that $\sim 76$ to $91 \%$ is released back to the atmosphere prior to snowmelt. Mercury deposited to the snowpack as GEM comprises the majority of snowmelt Hg and has a Hg stable isotope composition similar to $\mathrm{Hg}$ deposited by reactive surface uptake of GEM into the leaves of trees in temperate forests. This GEM-sourced $\mathrm{Hg}$ is the dominant $\mathrm{Hg}$ we measured in the spring snowpack and in tundra peat permafrost deposits.

\section{SUBJECT TERMS}

Arctic regions, Snow, Mercury-Isotopes, Atmospheric deposition

\section{SECURITY CLASSIFICATION OF:}

\section{a. REPORT}

Unclassified

\section{b. ABSTRACT}

Unclassified

\section{c. THIS PAGE}

Unclassified
17. LIMITATION OF ABSTRACT

SAR 18. NUMBER
OF PAGES

13 19a. NAME OF RESPONSIBLE PERSON

19b. TELEPHONE NUMBER (include area code) 